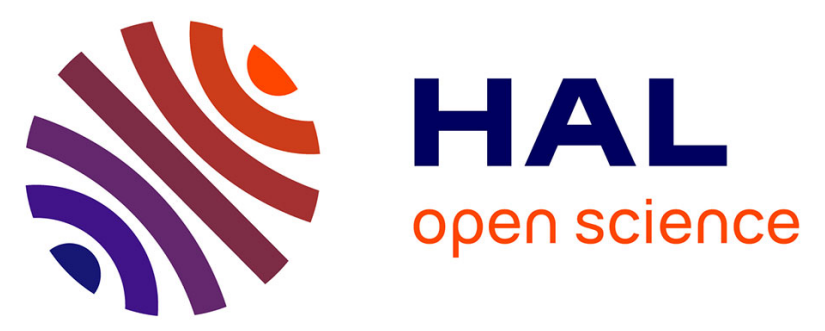

\title{
Effect of enthalpy-entropy compensation during sorption of water vapour in tropical woods: the case of Bubinga (Guibourtia Tessmanii J. Léonard; G. Pellegriniana J.L.)
} Y.N. Nkolo Meze'E, J. Noah Ngamveng, Sandrine Bardet

\section{- To cite this version:}

Y.N. Nkolo Meze'E, J. Noah Ngamveng, Sandrine Bardet. Effect of enthalpy-entropy compensation during sorption of water vapour in tropical woods: the case of Bubinga (Guibourtia Tessmanii J. Léonard; G. Pellegriniana J.L.). Thermochimica Acta, 2008, 468 (1-2), pp.1-5. 10.1016/j.tca.2007.11.002 . hal-00447212

\author{
HAL Id: hal-00447212 \\ https://hal.science/hal-00447212
}

Submitted on 12 Dec 2017

HAL is a multi-disciplinary open access archive for the deposit and dissemination of scientific research documents, whether they are published or not. The documents may come from teaching and research institutions in France or abroad, or from public or private research centers.
L'archive ouverte pluridisciplinaire HAL, est destinée au dépôt et à la diffusion de documents scientifiques de niveau recherche, publiés ou non, émanant des établissements d'enseignement et de recherche français ou étrangers, des laboratoires publics ou privés. 
Review

\title{
Effect of enthalpy-entropy compensation during sorption of water vapour in tropical woods: The case of Bubinga (Guibourtia Tessmanii J. Léonard; G. Pellegriniana J.L.)
}

\author{
Y.N. Nkolo Meze'e ${ }^{\mathrm{a}, *}, \mathrm{~J}$. Noah Ngamveng ${ }^{\mathrm{b}}$, S. Bardet ${ }^{\mathrm{c}}$ \\ ${ }^{a}$ University of Ngaoundere, Faculty of Science, B.P. 454, Ngaoundere, Cameroon \\ ${ }^{\mathrm{b}}$ Laboratoire de Physicochimie du Bois, Yaounde I University, Cameroon \\ ${ }^{\mathrm{c}}$ Laboratoire de Mécanique et Génie Civil, University Montpellier II, France
}

\begin{abstract}
The study of sorption of water vapour by a tropical wood (Bubinga) at $20^{\circ} \mathrm{C}, 38^{\circ} \mathrm{C}, 50^{\circ} \mathrm{C}$ and $60^{\circ} \mathrm{C}$ has permitted to obtain adsorption and desorption isotherms. Sigmoids have been obtained and they all show hysteresis phenomenon. From these isotherms, we were able to determine Gibbs energy, enthalpy and entropy variations. These variations were analysed and shown to be all negative for adsorption and all positive for desorption, with a great dependence to the moisture content during adsorption and desorption. Temperature had no significant effect on these parameters. Such dependence is mentioned in the scientific literature for softwood and is surely related to the availability of sorption sites. A linear relationship between enthalpy and entropy was shown to exist and the effect of enthalpy-entropy was studied for adsorption and desorption of water vapour by wood. In fact, the isokinetic temperature was determined and compared to the harmonic mean of temperatures.
\end{abstract}

Keywords: Sorption; Tropical wood; Thermodynamic properties; Gibbs energy; Isokinetic temperature

\section{Contents}

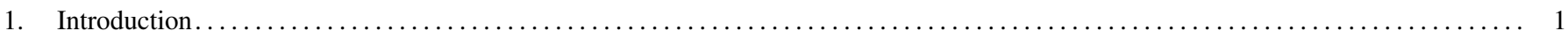

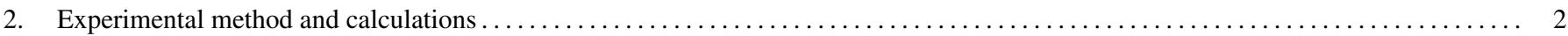

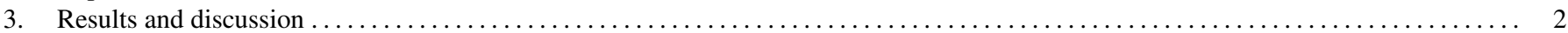

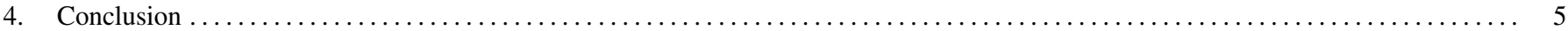

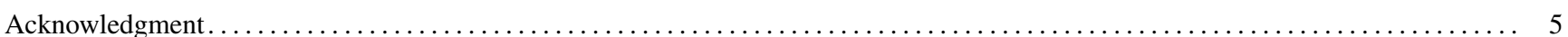

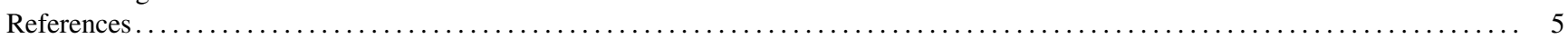

\section{Introduction}

Wood is a natural, fibrous and hygroscopic material. It always contains water (a great amount is taken off before use) and continuously exchanges water vapour with its environmental moisture by taking in water when atmospheric relative humidity is high (adsorption) and releasing water when relative humidity

\footnotetext{
* Corresponding author. Tel.: +273 77724958.

E-mail address: nkolo@ hotmail.com (Y.N. Nkolo Meze'e).
}

is low (desorption) $[1,2,13]$. The thermodynamics of moisture sorption in wood has become increasingly important with the rising interest in process modelling (e.g. drying) and also with the economic interest of optimisation of drying process, which involves exchange of moisture between wood and the environment. Determination of the thermodynamic parameters allows for a fuller interpretation of the sorption isotherms and provides a better insight into the sorption mechanism $[3,8]$. It has been observed that for a number of physical, chemical and biological systems, a linear relationship exists between changes in enthalpy and in entropy. This relationship is often 
called enthalpy-entropy compensation or isokinetic effect. The enthalpy-entropy compensation has been widely investigated for different physical and chemical processes. Bell [4] found a linear relation between the energy and entropy of solution for different solutes in the same solvent. Everett [5] reconfirmed this relationship for the adsorption of vapour on charcoal, glass and metals. Labuza [6] showed that it applied well to the thermal death of microorganisms, protein denaturation and ascorbic acid degradation in several food systems. Fontan et al. [7] showed the same linear relation for water sorption in some foods. Changes in enthalpy $(\Delta H)$ may provide a measure of energy changes that occur upon mixing of water molecules with wood during sorption and may be associated with the binding forces of the system. Free energy changes $(\Delta G)$, may be indicative of the sorbent's affinity for water based on its sign and provide a criterion whether water sorption is a spontaneous process or not. Finally, changes in entropy $(\Delta S)$ during sorption, may be associated with the spatial arrangements occurring in the water-wood interface in a defined state $[8,9]$. Other studies were done about enthalpy-entropy compensation and they all recommended more detailed investigations of this phenomenon. These studies have been done on temperate woods. In the present study, we determine the various thermodynamics parameters for both adsorption and desorption isotherms of Bubinga, a tropical wood. The aim is to find out if this linear relation exists in a tropical wood, and also to verify that is a characteristic of both adsorption and desorption - wood being not a perfectly elastic material, the kinetics of adsorption and desorption differ.

\section{Experimental method and calculations}

The species used in this study is Bubinga: Guibourtia Tessmanii J. Léonard; G. Pellegriniana J.L. Its density at $12 \%$ moisture content is in the range of $800-950 \mathrm{~kg} / \mathrm{m}^{3}$ with a mean value of $870 \mathrm{~kg} / \mathrm{m}^{3}$. Bubinga is a hardwood with a good natural resistance to fungi, termites and woodborers. This species is widely used in furniture and as building materials. Wood veneers were kindly supplied by ECAM PLACAGE Company. Sorption isotherms at $20^{\circ} \mathrm{C}, 38^{\circ} \mathrm{C}, 50^{\circ} \mathrm{C}$ and $60^{\circ} \mathrm{C}$ were determined with $2 \mathrm{~cm} \times 1 \mathrm{~cm} \times 0.06 \mathrm{~cm}$ specimens made from Bubinga clear wood free from any visual defects. They were sufficiently thin so that one could neglect the diffusion of water in the wood considered as rate controlling factor of the adsorption and desorption; they were wide enough to be measured by an electronic balance at $0.1 \mathrm{mg}$ accuracy. They were initially oven-dried at $(105 \pm 2)^{\circ} \mathrm{C}$ during $24 \mathrm{~h}$, placed in a desiccator containing anhydrous phosphorous pentoxide $\left(\mathrm{P}_{2} \mathrm{O}_{5}\right)$ and were evacuated to obtain $0 \%$ relative humidity. The dried specimens were exposed at relative humidities ranged between 11 and $98 \%$, each $24 \mathrm{~h}$ (till the equilibrium was observed). These relative humidities were obtained with saturated salt solutions, the salts solutions used in our experiments are: $\mathrm{LiCl}, \mathrm{C}_{2} \mathrm{H}_{3} \mathrm{O}_{2} \mathrm{~K}, \mathrm{MgCl}_{6} \cdot 2 \mathrm{H}_{2} \mathrm{O}, \mathrm{KSCN}$, $\mathrm{NaI} \cdot 2 \mathrm{H}_{2} \mathrm{O}, \mathrm{NaNO}_{2}, \mathrm{NaCl}, \mathrm{KBr}, \mathrm{BaCl}_{2} \cdot 2 \mathrm{H}_{2} \mathrm{O}$ and $\mathrm{CuSO}_{4} \cdot 5 \mathrm{H}_{2} \mathrm{O}$ $[10,15,16]$. The specimens were weighted and thus adsorption and desorption isotherms were obtained.

During adsorption and desorption, changes in Gibbs energy $(\Delta G)$, enthalpy $(\Delta H)$ and entropy $(\Delta S)$ occurred. $\Delta G$ is a func- tion of temperature and relative humidity:

$\Delta G=\mp R T \ln h$

where $h$ is the relative humidity; $R$ is the gas law constant $(=8.36 \mathrm{~J} / \mathrm{mol})$ and $T$, the absolute temperature $(\mathrm{K})$. For desorption, the changes are positive, while they are negative in the case of adsorption $[9,14]$.

The Gibbs free energy equation is:

$\Delta G=\Delta H-T \Delta S$

Combining Eqs. (1) and (2) we get:

$\ln h=\mp\left(\frac{\Delta H}{R T}-\frac{\Delta S}{R}\right)$

Entropy changes can also be calculated by the equation:

$\Delta S=\frac{(\Delta H-\Delta G)}{T}$

The enthalpy-entropy compensation was calculated from a plot of $\Delta H$ against $\Delta S$. The equation is of the form:

$\Delta H=T_{\mathrm{b}} \Delta S+A$

where $T_{\mathrm{b}}$ is the isokinetic temperature according to Leffler [11] and $A$ being a constant which has dimensions of energy.

The isokinetic temperature was therefore compared to the harmonic mean of temperature, $T_{\mathrm{hm}}$ :

$T_{\mathrm{hm}}=\frac{n}{\sum_{i}^{n} 1 / T}$

where $n$ is the number of isotherms.

According to Krug et al. [12] the compensation only exists if $T_{\mathrm{b}} \neq T_{\mathrm{hm}}$.

\section{Results and discussion}

The sorption isotherms obtained all exhibit the hysteresis phenomenon. They showed the typical sigmoid shape of type II, according to the BET classification [17]. The $\Delta G$ values range from $-9.577 \mathrm{~kJ} / \mathrm{mol}$ at $2 \%$ to $-0.251 \mathrm{~kJ} / \mathrm{mol}$ at $14 \%$. All these values are negative, confirming the strong attraction between the water molecules and the wood justifying equally the strong hygroscopic nature of the wood. This negative tendency of $\Delta G$ is expected from the thermodynamic point of view because adsorption is a spontaneous process. Furthermore, the Gibbs free energy is tied to work necessary to make the sorption sites available to the swelling of the wood structure; the higher the moisture content, the lower the number of available sites. The increase in temperature provokes the reduction of the moisture content of the wood, which also explains the reduction when temperature is increased. This is in total agreement with observations in the literature. Plot of $\ln h$ against $1 / T$ at six different moisture contents were obtained for adsorption and desorption (Figs. 1 and 2), respectively. The values of $\Delta H$ and $\Delta S$ corresponding to different moisture content levels, were calculated by fitting Eq. (3) through linear regression. As pointed out by Avramidis [8], this procedure assumed that $\Delta \mathrm{H}$ and $\Delta \mathrm{S}$ did not 


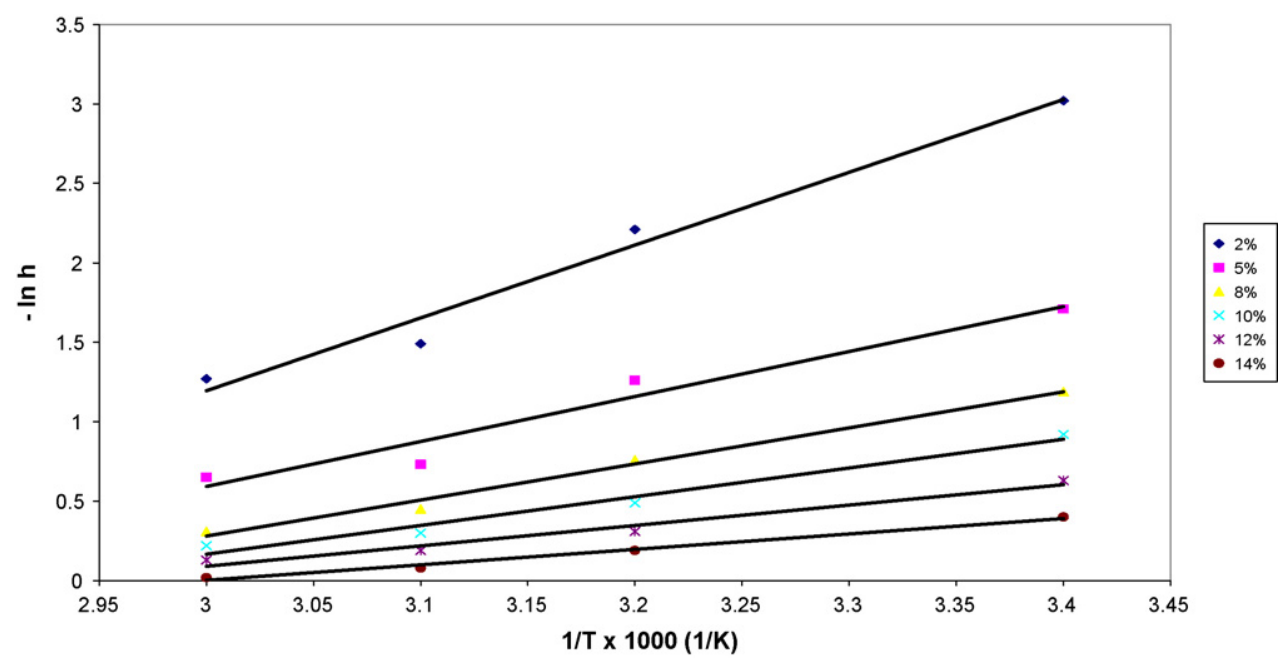

Fig. 1. Plot of logarithm of relative humidity as a function of temperature for different moisture contents (adsorption).

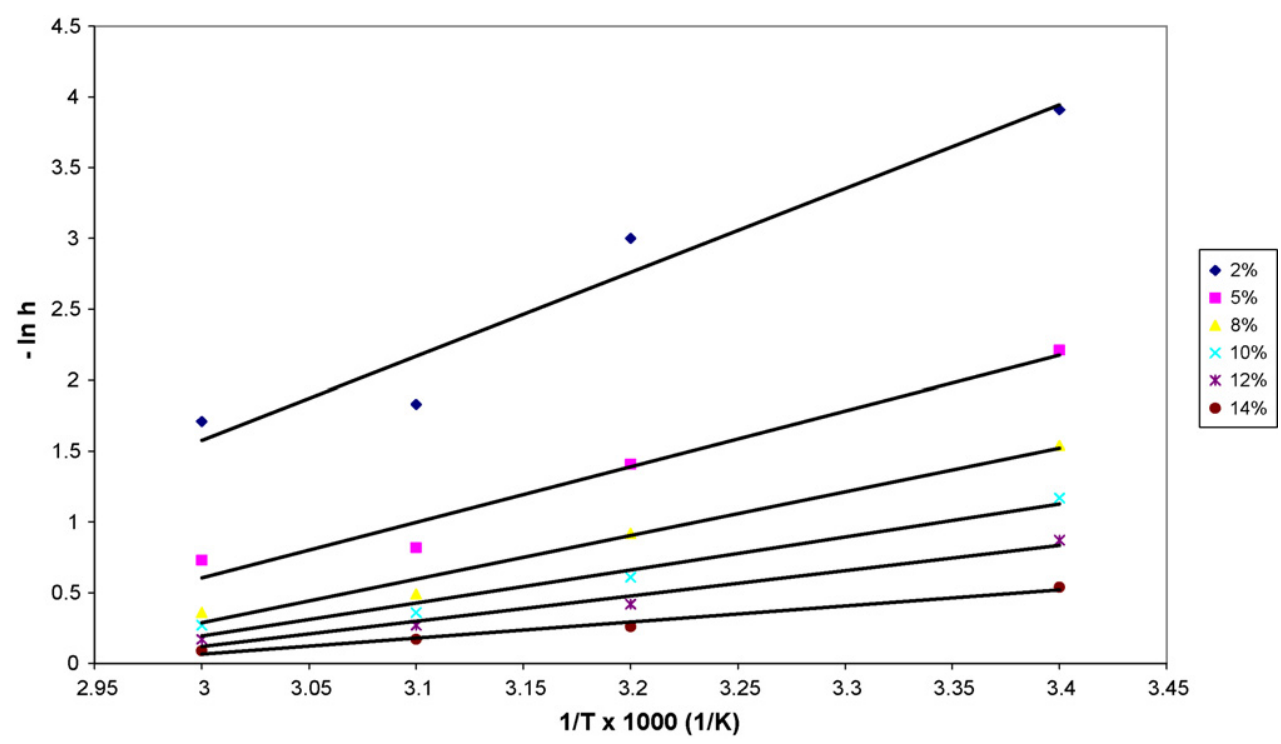

Fig. 2. Plot of logarithm of relative humidity as a function of temperature for different moisture contents (desorption).

vary with temperature or were initially constant in the temperature range under considerations. All $\Delta H$ values where equally negative and vary from $-38.289 \mathrm{~kJ} / \mathrm{mol}$ at $2 \%$ to $-8.661 \mathrm{~kJ} / \mathrm{mol}$ at $14 \%$.
Like for $\Delta G$ values, $\Delta H$ values become more negative as moisture increases. That trend confirms that the attractive forces of the water molecules by the sorption sites decreases when the moisture increases: at high moisture, the water molecules are

Table 1

Thermodynamic parameters as a function of moisture content and temperature for adsorption of water in wood (Bubinga)

\begin{tabular}{|c|c|c|c|c|c|c|c|c|c|c|}
\hline \multirow[t]{2}{*}{$M(\%)$} & \multicolumn{4}{|c|}{$-\Delta G(\mathrm{~kJ} / \mathrm{mol})$} & \multirow[t]{2}{*}{$-\Delta H(\mathrm{~kJ} / \mathrm{mol})$} & \multirow[t]{2}{*}{$-\Delta S^{\mathrm{a}}(\mathrm{kJ} / \mathrm{mol} \mathrm{K})$} & \multicolumn{4}{|c|}{$-\Delta S^{\mathrm{b}}(\mathrm{kJ} / \mathrm{mol} \mathrm{K})$} \\
\hline & $293 \mathrm{~K}$ & $311 \mathrm{~K}$ & $323 \mathrm{~K}$ & $333 \mathrm{~K}$ & & & $293 \mathrm{~K}$ & $311 \mathrm{~K}$ & $323 \mathrm{~K}$ & $333 \mathrm{~K}$ \\
\hline 2 & 7.397 & 5.746 & 1.023 & 3.535 & 38.289 & 0.105 & 0.105 & 0.105 & 0.106 & 0.104 \\
\hline 8 & 2.915 & 1.976 & 1.215 & 0.863 & 16.834 & 0.047 & 0.047 & 0.047 & 0.048 & 0048 \\
\hline 10 & 2.253 & 1.274 & 0.810 & 0.612 & 15.120 & 0.044 & 0.044 & 0044 & 0.044 & 0.044 \\
\hline 12 & 1.543 & 0.806 & 0.513 & 0.362 & 10.749 & 0.031 & 0.031 & 0.032 & 0.032 & 0.031 \\
\hline
\end{tabular}

${ }^{\text {a }} \Delta$ S: change in entropy calculated by Eq. (3).

b $\Delta S$ : change in entropy calculated by Eq. (4). 
Table 2

Thermodynamic parameters as a function of moisture content and temperature for desorption of water in wood (Bubinga)

\begin{tabular}{|c|c|c|c|c|c|c|c|c|c|c|}
\hline \multirow[t]{2}{*}{$M(\%)$} & \multicolumn{4}{|c|}{$\Delta G(\mathrm{~kJ} / \mathrm{mol})$} & \multirow[t]{2}{*}{$\Delta H(\mathrm{~kJ} / \mathrm{mol})$} & \multirow[t]{2}{*}{$\Delta S^{\mathrm{a}}(\mathrm{kJ} / \mathrm{mol} \mathrm{K})$} & \multicolumn{4}{|c|}{$\Delta S^{\mathrm{b}}(\mathrm{kJ} / \mathrm{mol} \mathrm{K})$} \\
\hline & $293 \mathrm{~K}$ & $311 \mathrm{~K}$ & $323 \mathrm{~K}$ & $333 \mathrm{~K}$ & & & $293 \mathrm{~K}$ & $311 \mathrm{~K}$ & $323 \mathrm{~K}$ & $333 \mathrm{~K}$ \\
\hline 2 & 9.577 & 7.799 & 4.942 & 4.760 & 49.515 & 0.135 & 0.136 & 0.138 & 0.138 & 0.134 \\
\hline 8 & 3.772 & 2.392 & 1.323 & 1.002 & 25.773 & 0.075 & 0.075 & 0.076 & 0.076 & 0.074 \\
\hline 10 & 2.866 & 1.586 & 0.972 & 0.752 & 19.515 & 0.057 & 0.057 & 0.057 & 0.044 & 0.056 \\
\hline 12 & 2.131 & 1.092 & 0.789 & 0.473 & 14.929 & 0.044 & 0.044 & 0.044 & 0.044 & 0.043 \\
\hline
\end{tabular}

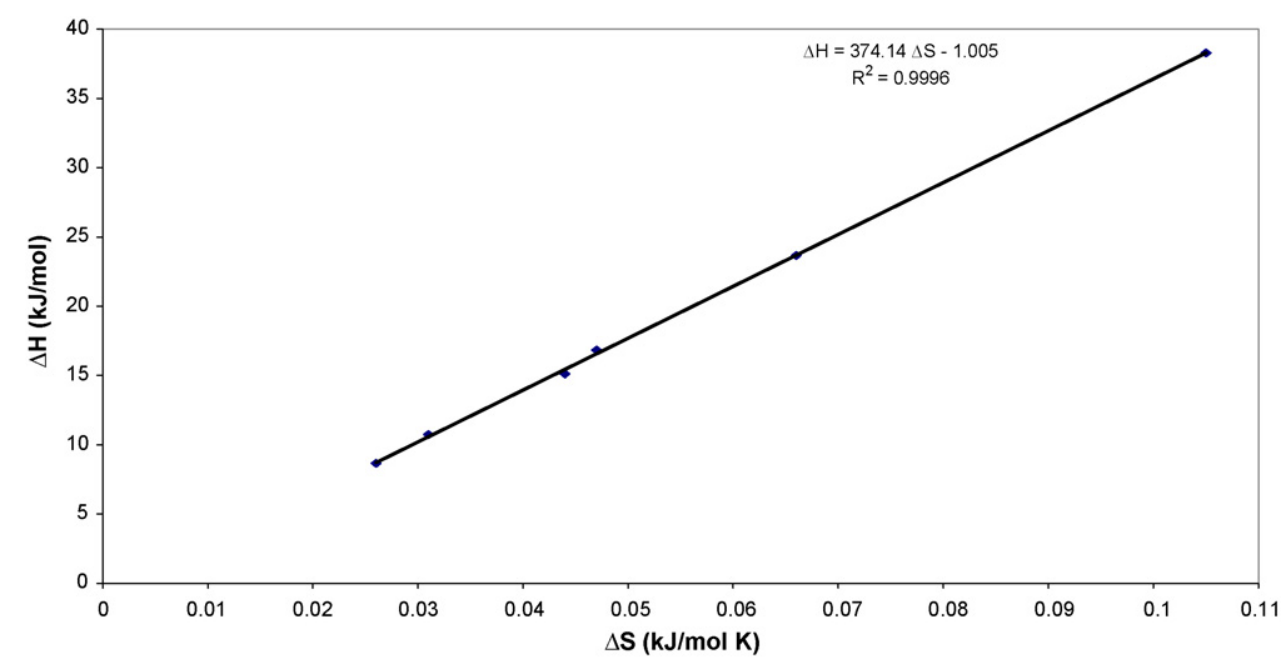

Fig. 3. Enthalpy changes as a function of entropy changes (in absolute value, adsorption).

weakly bound to the sorption sites. There is not a significant dependence with the temperature.

The $\Delta S$ values have been calculated by using two different equations (Eqs. (3) and (4)) and the results obtained are about the same. The changes in entropy being associated to the spatial arrangements of water molecules; it is a measure of the order of the sorbed water molecules. We observed that $\Delta S$ is greater at lower moisture contents (in absolute value), which shows that the sorbed water molecules are more ordered at lower moisture contents compared to higher moisture contents [1]. Tables 1 and 2 show that $\Delta S$ increases slightly with an increase in temperature.

Enthalpy-entropy compensation is calculated from a plot of $\Delta H$ versus $\Delta S$ for adsorption and desorption (Figs. 3 and 4), respectively. This plot produced a straight line and an equation of the form of Eq. (5) is obtained. $T_{\mathrm{b}}$ and $A$ were found to be $374.14 \mathrm{~K}$ and -1.005 . It should be noted that $A$ has dimensions

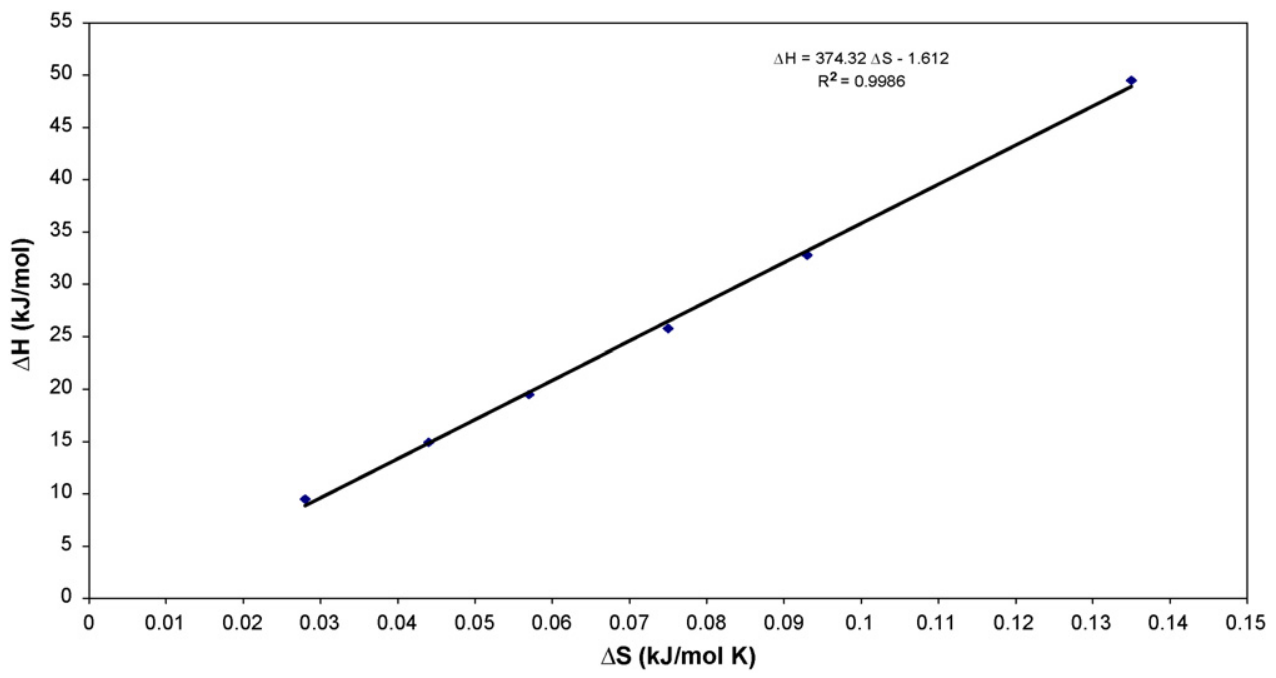

Fig. 4. Enthalpy changes as a function of entropy changes (desorption). 
of energy. Also, the linear enthalpy-entropy relationship (Eq. (5)) must be consistent with the Gibbs free energy relation (Eq. (2)). This consistency requires the nature of $A$ to be similar to that of changes in free energy, which is the energy required to do the work in swelling of the wood. Thus, $A$ is related to the degree of swelling, which, in turn, is related to the porosity and density of the wood.

The high value of the correlation coefficient (Fig. 3) suggests a linear relation between enthalpy and entropy and hence demonstrates the existence of enthalpy-entropy compensation for the wood-water system investigated in the present study. This is also proven the difference between $T_{\mathrm{b}}$ and $T_{\mathrm{hm}}\left(T_{\mathrm{hm}}=314.96 \mathrm{~K}\right)$, the harmonic mean of temperature.

For desorption, all the values are positive. $\Delta G$ values vary from $+9.577 \mathrm{~kJ} / \mathrm{mol}$ at $2 \%$ to $+0.251 \mathrm{~kJ} / \mathrm{mol}$ at $14 \%$. These positive values are normal because the desorption is a nonspontaneous process: the samples are pre-conditioned at a higher relative humidity degree then exposed at the lower relative humidity degree, till the equilibrium is attained. These values become less positive with increase in moisture content of the wood and in temperature.

The values of $\Delta H$ vary from $+49.515 \mathrm{~kJ} / \mathrm{mol}$ at $2 \%$ to $9.516 \mathrm{~kJ} / \mathrm{mol}$ at $14 \%$. These values show again the strong interaction between the wood and the water molecules. The decrease of $\Delta H$ as a function of the increase in moisture content and of temperature can be explained as follows: at higher moisture contents, the water molecules are weakly tied to sorption sites.

$\Delta S$ values have been also calculated by two different ways. And we observed the same phenomenon like in adsorption. The calculated values by these two methods give close results. The adsorption molecules are more ordered at weak moisture content of the wood as opposed to higher moisture content because $\Delta S$ increases as moisture decreases. The linear regression gives us $T_{\mathrm{b}}=374.32 \mathrm{~K}$ and $A=-1.612$ with a linear correlation coefficient, $r=0.9986$. The remarks done for $A$, for adsorption, are also true here. We also observed this strong linear relation between enthalpy and entropy confirming the enthalpy-entropy compensation because $T_{\mathrm{b}} \neq T_{\mathrm{hm}}$.

\section{Conclusion}

A linear relationship is proved to exist between enthalpy $(\Delta H)$ and entropy $(\Delta S)$ of adsorption and desorption of water in tropical wood, the case of Bubinga was studied. The thermodynamics parameters were determined and we believe that the availability of sorption sites must have a real influence on these thermodynamics parameters.

\section{Acknowledgment}

Special thank to IFS (International Foundation for Science) for their support.

\section{References}

[1] C. Skaar, Wood-water relationships in the chemistry of solid wood, Am. Chem. Soc., Springer Verlag, Berlin, 1984, pp. 127-172.

[2] A. Droin, J.L. Tavedet, J.M. Vergnaud, Wood Fiber Sci. 22 (1988) 1120.

[3] A. Themelin, Bois et for. des trop 256 (2) (1988) 55-67.

[4] R.P. Bell, Trans. Faraday Soc. 33 (1937) 496-501.

[5] D.H. Everett, Trans. Faraday Soc. 46 (1950) 957-969.

[6] I.P. Labuza, Food Tech. 34 (1980) 67-77.

[7] E.C. Fontan, J. Chirife, F. Sacho, H.A. Inglesias, J. Food Sci. 47 (1992) 1590-1594.

[8] S. Avramidis, Wood Sci. Tech. 26 (1992) 329-333.

[9] R.S. Rawat, D.P. Khali, J. Appl. Sci. 60 (1996) 787-790.

[10] M. Leiker, K. Aurich, 8th International IUFRO Wood Drying Conference, 2003, pp. 237-240.

[11] J.E. Leffler, J. Org. Chem. 20 (1955) 1202-1231.

[12] R.R. Krug, W.G. Hunter, R.A. Grieger, J. Phys. Chem. 80 (1976) 2335-2341.

[13] A. Ohandja, J.N. Noah, P. Morlier, Timb. Eng. 12 (2000) 36-42.

[14] W.P. Atkins, Chimie Physique, $6^{\mathrm{e}}$ éd., De Boeck Université, Paris, Bruxelles, 2000 (Chapter 28).

[15] Handbook of Chemistry and Physics, 77th ed., CRC Press Inc., 1996-1997, pp. $15-25$

[16] Wood Handbook-Wood as an Engeneering Material, Gen. Tech. Rep., FPL-GTR-113, Madison, WI, 1999 (Chapter 3).

[17] S. Brunauer, P.H. Emett, E. Teller, J. Am. Chem. Soc. 60 (1938) 309319. 